\title{
HUBUNGAN KECUKUPAN ASUPAN ZAT BESI DAN KADAR TIMBAL DARAH DENGAN KADAR HEMOGLOBIN ANAK JALANAN USIA KURANG DARI 8 TAHUN DI KAWASAN PASAR JOHAR SEMARANG
}

\author{
Putri Wohing Ati, Etisa Adi Murbawani*) \\ Program Studi Ilmu Gizi Fakultas Kedokteran Universitas Diponegoro \\ Jl.Dr.Sutomo No.18, Semarang, Telp (024) 8453708, Email : gizifk@undip.ac.id
}

\begin{abstract}
Background: The lead level in the air had an impact on the blood lead level of person who had high rate activities on the street, such as street children. High lead blood level might disrupt erythropoiesis process and the absorbtion of iron that can increase risk of anaemia. The heme synthesis disorders caused by the accumulation of lead become more serious when the sufficiency of body iron was unfulfilled. This research was aimed to analyze the association between iron sufficiency intake and lead blood level with haemoglobin level in respondents.

Method: This research using cross sectional design with 19 street children under 8 years old at Johar Market Area, Semarang, as subjects. The respondents were selected by purposive sampling. Data of iron intake sufficiency were obtained from interview using Semi Quantitative Food Frequency Questionnaire and the data was analyzed with Nutrisoft. The lead level was analyzed with AAS (Atomic Absorption Spectrophotometer) method. Lead blood level category consist of high $(>10 \mu \mathrm{g} / \mathrm{dL})$ and very high $(>40 \mu \mathrm{g} / \mathrm{dL})$. The haemoglobin level was analyzed with cyanmethemoglobin method with standard based on age group, for age between 6 months until 5 years old the rate were classified as normal if $>11 \mathrm{gr} / \mathrm{dl}$, and for range between 6 until 11 years old the rate were classified as normal if $>11,5 \mathrm{gr} / \mathrm{dl}$.

Result: Most of the respondents (64,8\%) consume iron lesser than the adequate number. The haemoglobin level of 6 respondents $(31,8 \%)$ were considered low. There were 26,3\% of respondents that had very high lead blood level, and then the rest $(73,7 \%)$ were in high category. There was correlation between iron intake sufficiency and haemoglobin level $(r=0.580, p=0.009)$ and there was also correlation between lead blood level with haemoglobin level $(r=-0,552, p=0,014)$.

Conclusion: There were relationship of iron intake sufficiency, lead blood level and haemoglobin rate in street children under 8 years of age at Semarang Johar Market Area.

Keyword: Iron intake sufficiency; lead blood level; hemoglobin level; street children
\end{abstract}

\begin{abstract}
ABSTRAK
Latar Belakang: Kadar timbal dalam udara mempunyai pengaruh terhadap kadar timbal dalam darah seseorang yang beraktivitas tinggi di jalanan, seperti pada anak jalanan. Kadar timbal dalam darah yang tinggi dapat mengganggu proses eritropoesis dan adanya gangguan sintesis heme yang diakibatkan oleh akumulasi timbal akan semakin buruk bila kecukupan zat besi tubuh tidak terpenuhi. Tujuan dari penelitian ini adalah untuk mengetahui hubungan kecukupan asupan zat besi dan kadar timbal dengan kadar hemoglobin responden.

Metode: Desain penelitian Cross Sectional pada 19 anak jalanan di kawasan Pasar Johar, Semarang. Responden dipilih secara purposive sampling. Data kecukupan asupan zat besi diperoleh dari wawancara dengan responden dan orangtua menggunakan kuesioner Food Frequency Questioner Semi kuantitatif dan dianalisis menggunakan Nutrisoft. Kadar timbal dianalisis menggunakan metode AAS (Atomic Absorption Spectrophotometer) dengan kategori tinggi $(>10 \mu \mathrm{g} / \mathrm{dL})$ dan sangat tinggi $(>40 \mu \mathrm{g} / \mathrm{dL})$. Kadar hemoglobin dianalisis dengan metode cyanmethemoglobin dengan standar berdasarkan kelompok usia yaitu 6 bulan -5 tahun tergolong normal jika >11 gr/dl dan 6-11 tahun >11,5 gr/dl. .
\end{abstract}

Hasil: Sebagian besar responden (64,8\%) mengonsumsi zat besi kurang dari angka kecukupan. Kadar Hb pada 6 responden (31,8\%) tergolong rendah. Kadar timbal responden sebanyak 73,7\% tergolong tinggi, dan 26,3\% tergolong sangat tinggi. Ada korelasi antara kecukupan asupan zat besi ddengan kadar hemoglobin $(r=0,580 ; p=0,009)$ dan ada korelasi antara kadar timbal dengan kadar hemoglobin $(r=-0,552 ; p=0,014)$.

Simpulan: Ada hubungan antara kecukupan asupan zat besi dan kadar timbal dengan kadar hemoglobin anak jalanan usia kurang dari 8 tahun di Kwasan Pasar Johar, Semarang.

Kata kunci: Kecukupan asupan zat besi; kadar timbal; kadar hemoglobin; anak jalanan.

\section{PENDAHULUAN}

Kualitas udara sangat dipengaruhi oleh padatnya transportasi di suatu wilayah. Menurut sebuah penelitian yang dilakukan di DKI Jakarta, kontribusi bahan pencemar kendaraan motor ke udara adalah sebesar $70 \% .^{1}$ Kota Semarang merupakan salah satu kota metropolitan dimana angka peningkatan jumlah kendaraan rata-rata 
pertahun mencapai 5-9\%, baik kendaraan berbahan bakar premium maupun solar. ${ }^{2}$ Pengoperasian kendaraan bermotor akan mengeluarkan polutan udara yang mempunyai dampak negatif, baik terhadap lingkungan maupun kesehatan manusia. ${ }^{3}$

Udara yang tercemar mengandung logam berbahaya sekitar $0,01 \%$ - $3 \%$ dari seluruh partikulat debu di udara. ${ }^{1}$ Emisi timbal sebagai buangan dari kendaraan bermotor masuk ke udara dalam bentuk gas. Emisi timbal merupakan efek samping dari pembakaran yang terjadi dalam mesin kendaraan yang berasal dari senyawa Tetra Etil Lead dan Tetra Metil Lead yang ditambahkan dalam bahan bakar. ${ }^{1}$

Timbal merupakan logam berat toksik tanpa fungsi dan tidak diperlukan keberadaannya oleh tubuh. ${ }^{4}$ Penggunaan bahan bakar seperti premium dan solar melepaskan 95\% emisi timbal yang dapat mencemari udara dan kemudian dapat dihirup serta diserap oleh tubuh sehingga menimbulkan gangguan kesehatan seperti mual, pusing, gangguan hematologi, pencernaan dan pernafasan hingga penurunan tingkat intelegensi. ${ }^{4}$

Kadar timbal pada udara mempunyai pengaruh terhadap kadar timbal dalam darah seseorang yang beraktivitas tinggi di jalanan. Kelompok orang yang sering berada di jalanan seperti polisi lalu lintas, pedagang kaki lima, pengemis, dan anak jalanan mempunyai risiko yang besar terkena paparan polutan udara yang dikeluarkan oleh kendaraan bermotor. ${ }^{5}$ Anak-anak akan lebih mudah terkontaminasi dibandingkan orang dewasa karena tubuh anak mengabsorbsi lebih dari 50\% timbal yang masuk dalam tubuh, sedangkan pada orang dewasa hanya $15-35 \%{ }^{4}$ Selain itu, pada anak-anak masih memiliki kebiasaan memasukkan tangan dan mainan kedalam mulut sehingga semakin memperbesar risiko tertelannya timbal ${ }^{5}$. Sebuah penelitian yang dilakukan di Bandung mengenai oral habit pada 223 anak menghasilkan bahwa kebiasaan seperti menggigit kuku, meghisap jari, dan bernafas melalui mulut terjadi paling banyak pada usia hingga 8 tahun. ${ }^{6}$

Penelitian yang dilakukan pada anak jalanan di Jogjakarta menyebutkan bahwa $72,7 \%$ responden memiliki kadar timbal yang melebihi batas yaitu $>10 \mu \mathrm{g} / \mathrm{dl}$ dan ada hubungan yang signifikan antara lama beraktivitas di jalan dengan kadar timbal dalam darah ${ }^{5}$. Penelitian lain yang dilakukan FKM UI dan $C D C$, diperoleh bahwa 44,8\% dari responden anak-anak usia sekolah dasar mempunyai kadar timbal dalam darah lebih dari $10 \mu \mathrm{g} / \mathrm{dl} .^{7}$
Kadar timbal dalam darah yang tinggi dapat mengganggu sistem hematologi karena mengganggu eritropoesis dengan menghambat sintesis protoporfirin dan mengganggu absorbsi zat besi sehingga dapat meningkatkan risiko anemia. ${ }^{8}$ Hasil penelitian pada anak jalanan di Jogjakarta menunjukkan bahwa $100 \%$ dari 30 responden memiliki konsentrasi timbal dalam darah yang melebihi ambang batas normal $10 \mu \mathrm{g} / \mathrm{dl}$, dan $70,08 \%$ diantaranya menderita anemia. ${ }^{9}$

Adanya gangguan sintesis hemoglobin yang diakibatkan oleh akumulasi timbal diperberat bila kecukupan asupan zat besi tubuh tidak terpenuhi. Anak yang mengalami defisiensi besi akan menyerap timbal 2 hingga 3 kali lebih banyak dibandingkan dengan anak yang cukup asupan zat besinya $^{8}$. Zat besi dan timbal akan berinteraksi dan berkompetisi dalam proses sintesis hemoglobin. Hasil penelitian pada anak jalanan yang dilakukan di Bandung menyebutkan bahwa lebih dari separuh responden $(70,6 \%)$ memiliki tingkat kecukupan asupan zat besi kurang. ${ }^{10}$

Berdasarkan latar belakang diatas, maka perlu diteliti mengenai hubungan kecukupan asupan zat besi dan kadar timbal dengan kadar hemoglobin anak-anak jalanan yang berusia kurang dari 8 tahun.

\section{METODE PENELITIAN}

Penelitian ini dilakukan pada anak-anak jalanan yang ada di kawasan Pasar Johar, Semarang. Waktu pelaksanaan penelitian ini adalah bulan Maret-Mei 2014. Ruang lingkup penelitian merupakan penelitian gizi masyarakat dengan desain penelitian cross sectional. Jumlah subjek total dalam penelitian ini adalah 23 anak yang dipilih secara purposive sampling, namun pada pelaksanaannya hanya 19 anak yang bersedia menjadi responden dikarenakan orang tua dan anak menolak untuk terlibat dalam penelitian ini. Kriteria inklusi dalam penelitian ini adalah anak jalanan yang telah mendapat persetujuan orangtua dan bersedia menjadi responden penelitian, berusia tidak lebih dari 8 tahun, tidak dalam keadaan sakit atau perawatan dokter dan melakukan aktivitas di jalanan minimal 6 jam sehari. Aktivitas berupa aktivitas di jalanan yang bersifat ekonomi seperti mengamen, mengemis, menjual koran atau hanya aktivitas bermain di jalanan.

Variabel bebas dalam penelitian ini adalah asupan zat besi dan kadar timbal, sedangkan variabel terikat adalah kadar hemoglobin. Variabel perancu adalah asupan fitat sebagai penghambat absorbsi zat besi dalam tubuh, serta asupan seng 
(Zn) dan copper $(\mathrm{Cu})$ sebagai kompetitor timbal $(\mathrm{Pb})$.

Asupan zat besi didefinisikan sebagai jumlah zat besi yang dikonsumsi dalam sehari yang diperoleh melalui formulir $F F Q$ semi kuantitatif dan dianalisis menggunakan nutrisoft. Jumlah asupan zat besi perhari dibandingkan dengan standar kebutuhan individu normal menurut usia. Usia 4-6 tahun kecukupan asupan zat besi sebesar $8 \mathrm{mg} /$ hari, sedangkan untuk usia 7-9 tahun kecukupannya sejumlah $10 \mathrm{mg} / \mathrm{hari}^{11}$.

Kadar timbal dalam darah diartikan sebagai kadar timbal dalam darah responden yang diukur dengan metode Atomic Absorbic Spektofotometer (AAS) dengan satuan $\mu \mathrm{g} / \mathrm{dl}$. Menurut CDC (Center for Disease Control and Prevention) kadar timbal dikatakan normal jika $<10 \mu \mathrm{g} / \mathrm{dl}$ dan tinggi jika $>10 \mu \mathrm{g} / \mathrm{dl}^{12}$. Pengkategorian kadar timbal dalam penelitian ini adalah tinggi dan sangat tinggi, hal ini didasarkan pada pengaruhnya terhadap kadar $\mathrm{Hb}$. Kadar timbal pada kategori sangat tinggi $(>40$ $\mu \mathrm{g} / \mathrm{dl})$ dapat memberikan pengaruh pada kadar hemoglobin responden yang rendah ${ }^{4}$.

Kadar hemoglobin didefinisikan sebagai kadar hemoglobin pada responden yang diukur menggunakan metode cyanmethemoglobin. Anak berusia 6 bulan -5 tahun dikatakan normal jika kadar $\mathrm{Hb}>11 \mathrm{gr} / \mathrm{dl}$, sedang untuk anak berusia 6 11 tahun normal jika kadar $\mathrm{Hb}>11,5 \mathrm{gr} / \mathrm{dl}^{18}$.

Langkah pertama yang dilakukan dalam penelitian ini adalah penapisan terhadap calon responden yang sesuai dengan kriteria inklusi. Kemudian, setelah mendapatkan responden yang sesuai dengan kriteria inklusi maka dilakukan pendekatan terhadap responden dan orang tua selama 1 bulan. Tahap setelah pendekatan adalah pengambilan data, baik darah maupun asupan zat besi responden. Pengukuran asupan zat besi dilakukan dengan menggunakan formulir $F F Q$ semi kuantitatif dan hasilnya dibandingkan dengan angka kecukupan gizi berdasarkan usia.

Data yang diperoleh kemudian dianalisis menggunakan analisis bivariat dan multivariat. Analisis bivariat untuk mengetahui hubungan variabel terikat dan terikat dengan menggunakan uji korelasi Pearson karena data berdistribusi normal. Analisis korelasi parsial digunakan untuk melihat pengaruh variabel perancu yaitu asupan fitat, seng dan tembaga. Analisis multivariat dengan menggunakan regresi linier ganda.

\section{HASIL PENELITIAN \\ Karakteristik responden}

Tabel 1. Karakteristik Responden

\begin{tabular}{lcccc}
\hline & & \multicolumn{2}{c}{ Jenis Kelamin Responden } & \\
\cline { 2 - 4 } & & Perempuan & Laki-laki & Total \\
\hline Umur Responden & $4-6$ & 5 & 3 & 8 \\
& $7-8$ & 4 & 7 & 11 \\
Total & & 9 & 10 & 19 \\
\hline
\end{tabular}

Lebih dari separuh responden $(52,6 \%)$ adalah laki-laki dan sisanya yaitu $47,4 \%$ adalah perempuan. Usia responden berkisar mulai dari 4 hingga 8 tahun dan sebagian besar responden berusia 7-8 tahun. Seluruh responden memiliki aktivitas di jalanan minimal 6 jam perhari, dengan beberapa aktivitas ekonomi di jalanan seperti mengamen, mengemis, menjual koran maupun hanya bermain bersama teman lain di jalanan.
Responden yang bersekolah akan memulai aktivitas di jalanan sepulang dari sekolah dan sesekali berlanjut di malam hari. Hari Jumat merupakan hari dimana hampir seluruh dari responden akan mengemis di kawasan Masjid Kauman.

Deskripsi kecukupan asupan besi, kadar timbal dan kadar hemoglobin

Tabel 2. Distribusi Subyek Berdasarkan Kecukupan Asupan Zat Besi, Kadar Timbal dan Kadar Hemoglobin

\begin{tabular}{lccccc}
\hline & n & $(\%)$ & Minimum & Maksimum & $\begin{array}{c}\text { Rerata } \\
(\text { Mean } \pm \text { SD })\end{array}$ \\
\hline Kecukupan asupan zat besi & & & $4.83 \mathrm{mg}$ & $20.11 \mathrm{mg}$ & $9.32 \pm 3.60$ \\
$\quad$ Cukup & 6 & 31.6 & & & \\
$\quad$ Kurang & 13 & 68.4 & & & \\
\hline Kadar timbal darah & & & $13.03 \mu \mathrm{g} / \mathrm{dl}$ & $49.49 \mu \mathrm{g} / \mathrm{dl}$ & $34.74 \pm 9.02$ \\
$\quad$ Tinggi & 14 & 73,7 & & &
\end{tabular}




\begin{tabular}{lccccc}
\hline & n & $\mathbf{( \% )}$ & Minimum & Maksimum & $\begin{array}{c}\text { Rerata } \\
\text { (Mean } \pm \text { SD) }\end{array}$ \\
\hline $\begin{array}{l}\text { Kecukupan asupan zat besi } \\
\quad \text { Cukup }\end{array}$ & 6 & 31.6 & $4.83 \mathrm{mg}$ & $20.11 \mathrm{mg}$ & $9.32 \pm 3.60$ \\
$\quad$ Kurang & 13 & 68.4 & & & \\
\hline$\quad$ Sangat tinggi & 5 & 26,3 & & & \\
\hline Kadar hemoglobin & & & $8.80 \mathrm{gr} / \mathrm{dl}$ & $14.10 \mathrm{gr} / \mathrm{dl}$ & $12.18 \pm 1.23$ \\
$\quad$ Normal & 13 & 68,4 & & & \\
$\quad$ Rendah & 6 & 31,6 & & & \\
\hline
\end{tabular}

Sebagian besar responden $(68,4 \%)$ mengonsumsi zat besi kurang dari angka kecukupan yang direkomendasikan, sedangkan sisanya 6 anak $(31,6 \%)$ tergolong cukup dengan rentang asupan mulai dari 4,83/hari hingga 20,11 $\mathrm{mg} / \mathrm{hari}$. Kadar timbal responden dikategorikan tinggi dan sangat tinggi, pada 5 responden $(26,3 \%)$ yang tergolong mempunyai kadar timbal sangat tinggi $(>40 \mu \mathrm{g} / \mathrm{dl})$ mempunyai kadar hemoglobin yang rendah. Rerata kadar timbal darah responden sebesar $34.74 \pm 9.02 \mu \mathrm{g} / \mathrm{dl}$ dengan rentang mulai dari $13,03 \mu \mathrm{g} / \mathrm{dl}$ hingga 49,49 $\mu \mathrm{g} / \mathrm{dl}$. Sebagian besar kadar hemoglobin responden $(68,4 \%)$ bernilai normal dengan rerata $12.18 \pm 1.23 \mathrm{gr} / \mathrm{dl}$.

Hubungan kecukupan asupan zat besi, kadar timbal dengan kadar hemoglobin

Tabel 3. Hubungan Kecukupan Asupan Zat Besi, Kadar Timbal dengan Kadar Hemoglobin

\begin{tabular}{lcccc}
\hline & \multicolumn{2}{c}{ Kecukupan Asupan Zat Besi } & \multicolumn{2}{c}{ Kadar Timbal } \\
\cline { 2 - 5 } & $\mathbf{r}$ & $\mathbf{p}$ & $\mathbf{r}$ & $\mathbf{P}$ \\
\hline Kadar & 0,580 & 0,009 & $-0,552$ & 0,014 \\
Hemoglobin & & & & \\
\hline
\end{tabular}

Hasil uji Pearson menunjukkan bahwa ada hubungan dan korelasi negatif antara kadar hemoglobin dengan kadar timbal ( $r=-0,552)$. Adanya hubungan negatif jika kadar timbal naik akan mengakibatkan turunnya kadar hemoglobin, dan berlaku untuk sebaliknya. Hubungan dan korelasi positif ditunjukkan dalam uji hubungan antara kecukupan asupan zat besi dengan kadar hemoglobin $(r=0,580 ; p=0,009)$. Korelasi positif menunjukkan bahwa jika angka kecukupan asupan zat besi semakin baik maka kadar hemoglobin akan naik.

Hubungan antara kecukupan asupan zat besi dan kadar timbal darah dengan kadar hemoglobin setelah di kontrol variabel perancu

Tabel 7. Hubungan Kecukupan Asupan Zat Besi dan Kadar Timbal Darah dengan Kadar Hemoglobin Setelah di Kontrol Variabel Perancu

\begin{tabular}{llcc}
\hline Variabel Perancu & Variabel Bebas & \multicolumn{2}{c}{ Kadar Hemoglobin } \\
\cline { 3 - 4 } & & $\mathbf{r}$ & $\mathbf{p}$ \\
\hline Asupan fitat & Asupan zat besi & 0,628 & 0,005 \\
\hline Asupan zinc & Kadar timbal darah & $-0,316$ & 0,216 \\
Asupan copper & & & \\
\hline
\end{tabular}

Fitat merupakan penghambat absorbsi zat besi dalam tubuh sehingga akan berpengaruh terhadap bioavailabilitas zat besi dalam tubuh. Setelah dilakukan uji korelasi parsial didapatkan hasil bahwa asupan zat besi setelah dikontrol oleh asupan fitat memiliki hubungan yang bermakna terhadap kadar hemoglobin.

Hasil uji korelasi parsial menunjukkan bahwa kadar timbal darah setelah dikontrol oleh asupan seng dan copper tidak bermakna secara statistik dengan nilai korelasi negatif. Hal ini berarti bahwa jika kadar timbal setelah dikontrol asupan seng dan copper naik akan mengakibatkan kadar hemoglobin turun.

Hubungan antara kecukupan asupan zat besi dan kadar timbal darah dengan kadar hemoglobin 
Tabel 8. Hasil Uji Statisik Hubungan Semua Variabel

\begin{tabular}{lcc}
\hline & Variabel & Kadar Hemoglobin \\
\cline { 2 - 2 } & Kadar $\mathrm{Pb}$ & 0,588 \\
Asupan besi & 0,008 \\
Asupan fitat & 0,288 \\
Asupan $\mathrm{Cu}$ & 0,066 \\
Asupan $\mathrm{Zn}$ & 0,541 \\
\hline
\end{tabular}

Analisis multivariat menunjukkan bahwa hanya variabel asupan zat besi dapat mempengaruhi kadar hemoglobin responden secara signifikan (nilai $\mathrm{p}<0.05$ ). Dalam analisis data regresi linier berganda didapatkan $r$ sebesar 0,826 dan nilai $\mathrm{p}$ seperti yang tertera pada tabel 8 .

\section{PEMBAHASAN}

\section{Karakteristik responden}

Penelitian ini melibatkan anak jalanan yang berusia kurang dari 8 tahun. Pembatasan usia dikarenakan adanya kecenderungan bahwa anakanak menyerap 50\% timbal lebih banyak dibandingkan pada dewasa. ${ }^{4}$ Selain itu, oral habbit pada anak usia 8 tahun tergolong masih tinggi sehingga akses masuknya timbal dari kebiasaan tersebut seperti memasukkan mainan maupun benda lain, menggigit kuku dan jari juga tinggi. ${ }^{6}$ Kuku pada seseorang yang memiliki paparan tinggi terhadap timbal secara kronis akan menjadi deposit timbal serta tempat menempelnya timbal yang terdapat pada mainan dan cat, oleh karenanya jika anak menggigit kuku, terlebih tanpa mencuci tangan terlebih dahulu, maka akan memperbesar kemungkinan tertelannya timbal ${ }^{13}$.

Responden yang bersedia hingga akhir menjadi responden sejumlah 19 anak, dengan 9 anak perempuan dan 10 anak laki-laki. Responden dalam penelitian ini memiliki aktivitas ekonomi di jalan yang cukup aktif, dengan kisaran waktu 6 jam per hari, baik sebagai pengamen, penjual koran, pengemis, atau sekedar hanya bermain di jalanan. Responden yang bersekolah maka akan memulai aktivitas di jalanan sepulang dari sekolah dan di waktu-waktu tertentu, seperti akhir pekan, akan berlanjut hingga malam hari. Wilayah kerja responden tersebar di beberapa tempat seperti Pasar Johar, perempatan Hotel Metro dan kawasan Masjid Kauman. Seluruh responden bertempat tinggal di kawasan sekitar Pasar Johar seperti daerah Sungai Berok, daerah parkiran Inak, dan Pasar Yak'i.

\section{Kecukupan asupan zat besi}

Hasil analisis kecukupan asupan zat besi didapatkan bahwa sebagain besar responden $(68,4 \%)$ tergolong kurang. Asupan zat besi responden berkisar dari $4,83 \mathrm{mg} /$ hari hingga $20,11 \mathrm{mg} /$ hari dengan rerata $9,32 \pm 3,60 \mathrm{mg} /$ hari. Rendahnya asupan zat besi responden dapat dipengaruhi oleh asupan protein hewani yang kurang. Sedangkan protein yang bersumber dari nabati memiliki bioavailabilitas yang lebih rendah jika dibandingkan protein hewani. Penelitian mengenai pola konsumsi anak jalanan di Bandung menyebutkan bahwa $>50 \%$ dari responden mengonsumsi zat besi kurang dari angka yang direkomendasikan, dan mengonsumsi protein hewani rendah serta hanya bersumber utama dari serealia dan kacang-kacangan ${ }^{15}$.

\section{Kadar timbal darah}

Seluruh responden dalam penelitian ini mempunyai kadar timbal diatas ambang batas untuk anak-anak yaitu $10 \mu \mathrm{g} / \mathrm{dl}$, dengan nilai minimal 13,03 $\mu \mathrm{g} / \mathrm{dl}$ maksimal 49,49 $\mu \mathrm{g} / \mathrm{dl}$ dan rerata $34,74 \pm 9,02 \mu \mathrm{g} / \mathrm{dl}$. Penggolongan tinggi dan sangat tinggi pada penelitian ini bertujuan memunculkan hubungan kadar timbal dan kadar $\mathrm{Hb}$ dalam uji statistik.

Menurut CDC (Center for Disease Control and Prevention) anak yang memiliki kadar timbal darah yang tinggi akan muncul gejala klinis yang berbeda di tiap interval kadarnya. Kadar $10 \mu \mathrm{g} / \mathrm{dl}-$ $19 \mu \mathrm{g} / \mathrm{dl}$ akan menimbulkan efek pertumbuhan yang lebih lambat, keluhan sakit kepala dan berat badan yang kerap turun. Kadar 20-39 $\mu \mathrm{g} / \mathrm{dl}$ akan memunculkan gangguan pada sistem syaraf, dan kadar 40-69 $\mu \mathrm{g} / \mathrm{dl}$ akan menimbulkan gangguan pada sistem hematologi ${ }^{4}$. Berdasarkan klasifikasi tersebut terdapat 5 responden yang kadar timbal $>40 \mu \mathrm{g} / \mathrm{dl}$ dengan kadar hemoglobin rendah.

\section{Kadar hemoglobin}

Hasil analisis $\mathrm{Hb}$ didapatkan nilai minimun $8,80 \mathrm{gr} / \mathrm{dl}$ dan maksimun $14,10 \mathrm{gr} / \mathrm{dl}$, dengan nilai rata-rata 9,32 gr/dl. Standar yang digunakan adalah berdasarkan usia maka didapatkan 13 anak $(68,4 \%)$ mempunyai nilai hemoglobin yang normal, sedangkan 6 anak sisanya $(31,6 \%)$ mempunyai kadar $\mathrm{Hb}$ yang rendah atau anemia. Kadar hemoglobin merupakan salah satu indikator yang digunakan untuk menegakkan diagnosis anemia. Meskipun kadar hemoglobin kurang peka terhadap deteksi awal kekurangan zat besi, tetapi 
kadar hemoglobin berguna untuk mengetahui seberapa berat anemia yang diderita. ${ }^{14}$ Penelitian pada anak jalanan di Jogjakarta tentang status anemia di tiga rumah singgah menyebutkan bahwa $20 \%$ dari 30 responden mengalami anemia. Anemia yang diderita responden tersebut dapat diakibatkan oleh beberapa faktor risiko seperti defisiensi zat besi, riwayat penyakit kronis dan konsumsi alkohol. ${ }^{16}$

\section{Hubungan kecukupan asupan zat besi dengan kadar hemoglobin}

Uji Pearson dilakukan untuk melihat hubungan antara kecukupan zat besi dengan kadar hemoglobin, dan hasilnya terdapat hubungan yang kuat dan signifikan $(\mathrm{r}=0,580 ; \mathrm{p}=0,009)$ antara kedua variabel tersebut. Terdapat 13 anak dari 19 responden terdapat 13 anak $(68,4 \%)$ mengonsumsi zat besi kurang dari angka kecukupan yang direkomendasikan, sedangkan sisanya 6 anak $(31,6 \%)$ tergolong cukup. Dari 13 responden yang kurang kecukupan asupan zat besinya, 6 responden $(46,1 \%)$ memiliki kadar $\mathrm{Hb}$ yang rendah dan 7 responden $(53,8 \%)$ sisanya memiliki kadar $\mathrm{Hb}$ normal.

Defisiensi zat besi menjadi salah satu penyebab utama yang paling banyak ditemukan pada kejadian anemia, namun defisiensi zat gizi lain (seperti protein, asam folat dan vitamin B12), inflamasi akut dan kronis, infeksi parasit dan gangguan pada sintesis hemoglobin juga dapat menyebabkan anemia ${ }^{19}$. Kekurangan salah satu atau beberapa zat gizi yang terlibat dalam pembentukan sel darah merah tersebut dalam jangka waktu yang lama dapat menyebabkan anemia karena berkurangnya produksi sel darah merah $^{19}$. Penelitian ini hanya mengambil zat besi sebagai salah satu zat gizi yang mempengaruhi kadar hemoglobin. Hal ini dikarenakan zat besi akan berinteraksi dan berkompetisi dengan timbal dalam proses sintesis hemoglobin. Adanya gangguan sintesis hemoglobin yang diakibatkan oleh akumulasi timbal, akan diperberat bila kecukupan zat besi tubuh tidak terpenuhi. ${ }^{17}$

Hubungan kecukupan asupan zat besi dengan kadar hemoglobin setelah dikontrol asupan fitat

Hasil uji korelasi parsial menunjukkan ada hubungan yang bermakna antara kecukupan asupan zat besi dengan kadar hemoglobin setelah dikontrol dengan asupan fitat sebagai variabel perancu. Adanya perbedaan nilai $r$ antara sebelum dan sesudah dikontrol oleh variabel perancu, menunjukkan bahwa asupan fitat menghambat penyerapan besi. Asam fitat yang terdapat dalam makanan dapat mengikat besi sehingga menghambat penyerapannya. Sebuah penelitian mengenai anemia pada atlet remaja menyebutkan bahwa zat penghambat absorbsi zat besi seperti fitat berkorelasi negatif dengan kadar hemoglobin atlet, artinya semakin banyak fitat dikonsumsi akan mengakibatkan turunnya kadar hemoglobin dan sebaliknya. ${ }^{20}$

\section{Hubungan kadar timbal dengan kadar hemoglobin}

Kekurangan jumlah hemoglobin pada beberapa responden yang asupan zat besinya tidak adekuat, selain dikarenakan kurangnya asupan zat besi, juga dapat disebabkan adanya kontaminasi logam berat seperti timbal. Adanya interaksi yang saling mengkait antara makronutrien, mikronutrien dan logam berat dapat mengganggu pembentukan hemoglobin dan konsentrasi hemoglobin menjadi rendah $^{19,20}$.

Berdasarkan uji korelasi didapatkan hasil bahwa kadar timbal memiliki hubungan dengan kadar hemoglobin $(\mathrm{r}=-0,552 ; \mathrm{p}=0,014) .5$ responden $(26,3 \%)$ yang tergolong kadar timbal sangat tinggi, mengalami anemia dan kecukupan asupan zat besi yang kurang. Keadaan asupan zat besi yang tidak adekuat dan timbal yang tinggi akan berbagi transporter yang sama dalam proses absorbsi di saluran gastrointestinal sehingga terjadi kompetisi dan peningkatan penyerapan timbal ${ }^{8,17}$. Sebuah studi longitudinal pada anak-anak menunjukkan bahwa anak yang defisiensi besi akan mempunyai risiko 4-5 kali lebih tinggi untuk mengalami keracunan timbal dibandingkan dengan mereka yang asupan zat besinya adekuat ${ }^{17}$.

Hasil yang didapat dalam penelitian ini sejalan dengan standar interval yang dikeluarkan oleh CDC bahwa kadar timbal dalam darah akan memberikan efek hematotoksisitas pada kadar hemoglobin jika melebihi $40 \mu \mathrm{g} / \mathrm{dl}^{9}$. Nilai $\mathrm{r}$ yang bernilai negatif pada uji korelasi berarti adanya kecenderungan jika kadar timbal naik maka akan menekan kadar hemoglobin. Penelitian mengenai kadar timbal pada petugas SPBU di Semarang menyebutkan bahwa adanya korelasi negatif antara kadar timbal dengan kadar hemoglobin ( $\mathrm{r}=-$ 0,$202 ; \mathrm{p}=0,283$ ). ${ }^{2}$

Efek hematotoksisitas timbal dengan cara menghambat sebagian besar enzim yang berperan dalam biosintesis heme. Diantara enzim yang terlibat dalam sintesis, enzim 5-aminolevulinik acid dehydrogenase (ALAD) dan ferrochatalase termasuk enzim yang paling rentan terhadap efek penghambatan timbal ini. Selain melalui penghambatan enzim, toksisitas timbal juga dapat mengakibatkan destruksi eritrosit sehingga memperpendek usia eritrosit atau dikenal dengan anemia hemolitik. ${ }^{21}$ 
Sebanyak $73,7 \%$ responden lainnya memiliki kadar timbal $<40 \mu \mathrm{g} / \mathrm{dl}$ dan tidak berefek pada kadar $\mathrm{Hb}$. Gejala klinis yang ditimbulkan akibat tingginya kadar timbal reponden yang kurang dari $40 \mu \mathrm{g} / \mathrm{dl}$ tidak ikut diteliti, sehingga tidak dapat diketahui apakah gejala klinik keracunan timbal tersebut dialami oleh responden atau tidak.

\section{Hubungan kadar timbal dengan kadar hemoglobin setelah dikontrol asupan Seng dan Copper}

Hasil uji korelasi parsial menunjukkan bahwa kadar timbal darah setelah dikontrol oleh asupan seng dan copper tidak bermakna secara statistik dengan nilai korelasi negatif ( $\mathrm{r}=$ 0,316; $\mathrm{p}=0,216)$. Meskipun tidak bermakna, namun adanya perbedaan nilai $r$ antara sebelum dan sesudah dikontrol oleh asupan seng dan copper menunjukkan bahwa kadar timbal setelah dikontrol oleh asupan seng dan copper memiliki hubungan dengan kadar hemoglobin.

Penyerapan timbal dalam gastrointestinal dapat meningkat dalam keadaan defisiensi zat besi, seng dan tembaga ${ }^{22}$. Timbal yang masuk akan mengganggu metabolisme dari $\mathrm{Fe}, \mathrm{Zn}$ dan $\mathrm{Cu}$ dengan adanya kompetisi pada transporter protein DMT 1 yang berperan pada transport metal divalent $\left({ }^{+2}\right)^{22,23}$.

\section{SIMPULAN}

Sebanyak 68,4\% responden memiliki kecukupan asupan zat besi yang kurang dari angka kecukupan zat besi dengan rata-rata asupan 9,32 $\pm 3,60$ mg. Kadar $\mathrm{Hb} 31,8 \%$ responden tergolong rendah dengan rerata $\mathrm{Hb}$ adalah $12,18 \pm$ $1,23 \mathrm{gr} / \mathrm{dl}$. Seluruh responden memiliki kadar timbal $>10 \mu \mathrm{g} / \mathrm{dl}$ dengan 6 responden memiliki kadar timbal yang sangat tinggi yaitu $>40 \mu \mathrm{g} / \mathrm{dl}$.

Ada hubungan antara kecukupan asupan zat besi dengan kadar $\mathrm{Hb} \quad(\mathrm{p}=0,009 ; \mathrm{r}=0,580)$. Terdapat hubungan antara kadar $\mathrm{Hb}$ dan kadar timbal dengan nilai $\mathrm{p}=0,014$ dan korelasi negatif antara kedua variabel tersebut $r=0,-552$. Kecukupan asupan zat besi setelah dikontrol dengan asupan fitat memiliki hubungan dengan kadar hemoglobin $(\mathrm{r}=0,628 ; \mathrm{p}=0,005)$ Kadar timbal setelah dikontrol oleh asupan seng dan copper memiliki hubungan dengan kadar hemoglobin namun tidak signifikan secara statistik dengan $r-0,316$ dan $p$ 0,216.

\section{SARAN}

Tingginya kadar timbal responden kiranya dapat diminimalisir dengan meningkatkan asupan sumber makanan yang dapat menekan absorbsi timbal seperti zat besi (Fe), seng ( $\mathrm{Zn}$ ) dan copper $(\mathrm{Cu})$ seperti daging, hati dan sayuran hijau. Perlu dilakukan edukasi mengenai bahaya timbal terutama kepada orangtua mengingat selama ini mereka tidak pernah mendapatkan informasi risiko paparan timbal yang tinggi pada anak-anak mereka. Untuk penelitian selanjutnya, untuk memperoleh hubungan yang lebih spesifik dan akurat perlu dilakukan variabel perancu yang lebih beragam dengan sampel yang lebih besar disertai dengan pengukuran status gizi secara biokimiawi lainnya.

\section{DAFTAR PUSTAKA}

1. Tri Tugaswati. Emisi Gas Buang Kendaraan Bermotor dan Dampaknya Terhadap Kesehatan. Jakarta. 2012.hal1-11

2. Mifbakhudin., Ulfa N. Profil Darah dan Status Gizi Petugas Operator SPBU yang terpapar Gas Buang $(\mathrm{Pb})$ Kendaraan Bermotor di Kota Semarang Timur. Prosiding Seminar Nasional Unimus; 2010.hal. 145151

3. Suhendro., Soedibyo H.P., Windhu P. Kandungan Timbal dalam Darah dan Dampak Kesehatan Pada Pengemudi Bus Kota AC dan Non AC di Kota Surabaya. Jurnal Kesehatan Lingkungan, Vol.3, No.2, Januari 2007:127-136

4. Anna F. Wagiu., F.H Wulur. Hubungan antara Kadar Timbal Udara dengan Kadar Timbal Darah Serta dampaknya pada Anak. Sari Pediatri, Vol.8, No.3, Desember 2008:238-243.

5. Hastuti, Hubungan Lama Beraktivitas di Jalan dengan Kadar Timbal $(\mathrm{Pb})$ (Penelitian Pada Anak Jalanan di Kota Yogyakarta). Skripsi. 2008. Universitas Gajah Mada:Yogyakarta.

6. Yohanna W., Riyanti, E. Gambaran Oral Habbit pada Anak Usia 6-12 Tahun.Skripsi. 2007. Universitas Padjajaran:Bandung.

7. Rachel Albalak. Pemaparan Timbal dan Anemia pada Anak-Anak di Jakarta, Indonesia. Laporan Akhir. Didanai oleh: US Environmental Protection Agency, US-Asia Environmental Partnership dan US Department of State. 2001

8. Lubis, B. Rosdiana, N. Nafianti, S. Rasyianti, O. Panjaitan, Flora Mindo. Hubungan Keracunan Timbal dengan Anemia Defisiensi Besi pada Anak. CDK-200.Vol.40.No ,2013. hal:17-23.

9. Saifudin Zukhri. Hubungan Antara Kadar Timah Hitam $(\mathrm{Pb})$ Darah dengan kadar Hemoglobin $(\mathrm{Hb})$ pada Anak Jalanan di Yogjakarta. Thesis. Universitas Gadjah Mada: Yogyakarta. 2007

10. Nur'aini. Pola Aktivitas, Konsumsi Pangan, Status Gizi dan Kesehatan Anak Jalanan di Kota Bandung. Skripsi. Institut Pertanian Bogor:Bogor. 2009

11. Hardinsyah,. Riyadi, Hadi., Napituwulu, Victor. Kecukupan Energi, Protein, Lemak dan karbohidrat. Departemen Gizi Masyarakat FEMA IPB dan Departemen Gizi FK UI.2013 
12. Godwin, Hillary A. Lead Exposure and Poisoning in Children. UCLA Institute of the Environment:California.2009

13. Suherni. Keracunan Timbal di Indonesia. The Lead Group Incorporated:Sydney.2010.hal1-10

14. I Made B., Ketut S., Tjokorda GD. Anemia Defisiensi Besi. Dalam Buku : Buku Ajar Ilmu Penyakit dalam Jilid II EdisiIV. Jakarta: Pusat Penerbitan FK UI;2006.p.634-40

15. Nur'aini. Mira Dewi. Pola Aktivitas, Konsumsi Pangan, Status Gizi dan Kesehatan Anak Jalanan di Kota Bandung. Jurnla Gizi dan Pangan, Juli 2009. 4(2), hal: 97-105.

16. Aini, Mashitah Nurul. Prevalensi Anemia Pada Anak Jalanan di Tiga Rumah Singgah di DIY dan Hubungannya dengan Tinjauan Etiologi Berdasarkan Indeks Eritrosit dan Faktor Resiko. Skripsi. Universitas Muhammadiyah Yogyakarta. Yogyakarta.2008

17. Kwong, Wilsoon $\mathrm{T}$. Interaction between Iron Deficiency and Lead Poisoning:Epimiology and Pathogenesis. John Hopkins University Schhol of Medicine;USA. 2004.

18. Bruening K., Kemp, Francis W., N Simione., Holding Y., Louria, Donalid B., Bogden, John D. Dietary Calcium Intake of Urban Children at Risk of Lead Poisoning. Environmental Health Perspective Vol 107 No 6 Juni 2009. p:431-435.

19. WHO. Haemoglobin Concentration for the Diagnosis of Anaemia and Assessment of Severity. Vitamin and Mineral Information System. World Health Organization:Geneva. 2011.p1-16

20. Agustin Syamsianah., Erma handarsari. Ketersediaan Sumber Zat Besi, Zat Pemacu dan Penghambat Absorbsi Zat Besi dalam Hubungannya dengan Kadar Hb dan Daya Tahan Fisik Atlet Senam Persani Jateng. Skripsi. Universitas Muhammadiyah Semarang:Semarang. 2009.

21. Shilu Tong,. Schirnding, Yasmin E., Taippawan Propamontol. Environmental Lead Exposure: a Public Health Problem of Global Dimensions. 2000. Bulletin of the World Health Organization 78(9)p:1068-1077.

22. Choi, Joong Weon. Kim, Soon Ki. Relationships of Lead, Copper, $\mathrm{Zn}$ and Cadmium Levels versus Hematopoiesis and Iron Parameters in Healthy Adolescents. Annals of Clinical and Laboratory Science Vol 35 No 4. 2005.p:428-434.

23. Miguel Arredondo.,Ronny Martinez., Nunez, Marco T., Manuel Ruz., Manuel Olivarez. Inhibition of Iron and Copper Uptake by Iron, Copper and Zinc. Bio Res 39.2006.p:95-102 